\section{Smola Storage Ferula Tadshikorum M. Pimen Plantations Storage For Years}

Halkuzieva Mokhira Asatullaevna, Assistant Of Jizzakh Polytechnic Institute, Uzbekistan

Rahmonkulov Umarkul, Doctor Of Biological Sciences, Professor Of Jizzakh State Pedagogical Institute, Uzbekistan
G open ACCESS

The American Journal of Agriculture and Biomedical Engineering JULY 2020

Page No.: 30-34

Volume-II Issue-VII

PUBLISHED: 30 JULY 2020

www.usajournalshub.com/inde

x.php/tajabe

Copyright: Original content from this work may be used under the terms of the Creative Commons Attribution 4.0 licence.

\title{
Abstract
}

This article provides information on the organization of plantations in the arable lands of Jizzakh region by sowing the seeds of FERULA TADSHIKORUM M. PIMEN in the arable lands and the change in the number of plant bushes over the years.

Keywords: Kovrak, plantation, lalmikor, plant, ferula foetida, f.tadshikorum, root, bud, resin, medicinal, afghan knife, soil, ton, natural.

\section{Introduction}

Among the useful plants, representatives of the family Ziradoshlar (Apiaceae L.) have a special place. In particular, the species of the genus Kovrak-Ferula L. have the most (180200) species in this family, and 63 species are found in the territory of the Republic. They are important essential oils, fodder, honey, medicinal, starchy, aromatic, food and technical plants [9]. Ferula L. contains resins and essential oils, which are used in medicine, food industry, lacquer, as a spice [2] [3] [4] [6].

In particular, the resin extracted from the roots of the plant Ferula tadshikorum and Ferula foetida contains many biologically active substances and is used in the treatment of various diseases. 


\section{Materials and Methods}

In recent years, our country has been producing resins from the roots of Ferula foetida (Bunge) Regel and Ferula tadshikorum, M. Pimen which are exported annually from the Republic in excess of 400 tons and from Tajikistan in the amount of 150 tons. [17] [18]Currently, the main income of the population comes from the production of resin in some regions. As a result of non-compliance of resin producers from these plants with the rules of obtaining resin from the plant, the natural reserves of resin-bearing ferules are declining sharply every year. Scientific research is being conducted on the biology, distribution and rational use of resin-containing fractures. In the territory of Jizzakh region in 2015-2019, plantations of several fragile species, including F. foetida, brought to the arable lands from different regions, are being planted in experimental fields, and the study of the preservation of its grasses for years. Life forms of plants I.A. Ramenskiy (1935), I.A. Ramensky et al. (1956), ecological-morphological features I.T. Serebryakov (1962) and I.T. Serebryakov et al. (1967) methods [8] [9] [10] [11] .For the identification of species from the materials of the Herbarium Center of the Institute of Botany of the Academy of Sciences of the Republic of Uzbekistan (Tashkent) and "Opredelitel rasteniy Sredney Azii" (T. IX. 1968-1993), EP Korovin (1947), A.L. Takhtadjyan ( 1978), S.P. Cherepanov (1981; 1995), M.G. Pimenov, et al. (1983) [2] [12] [13] [14].

F.tadshikorum M. Pimen. - uljan plant is a height of 1.5 - 1.8 meters, its stem has 1 or sometimes 2 branches and smells like garlic. The shape of the root is cylindrical, glabrous, the leaves are located at 45 degrees to the stem. The petals are yellowish, 2-2.5 $\mathrm{mm}$ long, oblong, the tip is turned inwards. Seed (mericarpis) is $1.5-2.0 \mathrm{~cm}$ long and $0.8-$ $1.0 \mathrm{~cm}$ wide, absolute (thousand grains) weight is $35-40 \mathrm{~g}$ and it is endemic plant of the Western Pamir Alay. [16]
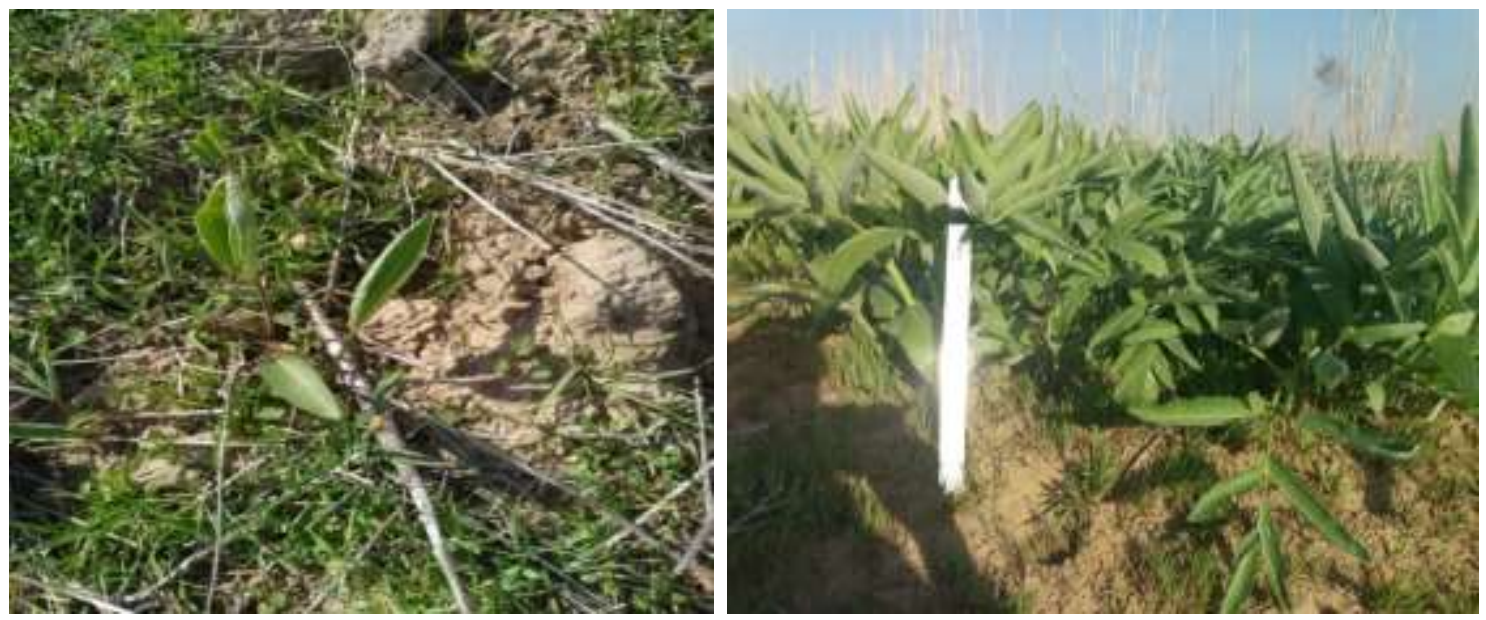

Figure 1. Vegetation of the second and fourth years of Ferula tadshikorum..

The seeds of plants growing in natural conditions were collected from different regions of the country and planted in the territory of "Shifo-kovrak" farm and "Uktam" farm of Arnasay district in 2014-2019. Information on the place of collection and sowing of F.tadshikorum seeds is given in Table 1 below. 


\section{Table-1}

Areas collected for the experiment and areas where seeds were planted

\begin{tabular}{|c|c|c|c|}
\hline $\begin{array}{l}\text { T. } \\
\text { C }\end{array}$ & $\begin{array}{l}\text { Place and date of seed } \\
\text { collection (year, month) }\end{array}$ & $\begin{array}{l}\text { Date of } \\
\text { seed } \\
\text { sowing }\end{array}$ & $\begin{array}{l}\text { The area where the seeds } \\
\text { are sown }\end{array}$ \\
\hline 1 & $\begin{array}{l}\text { Kashkhadary region, } \\
\text { Territory of Dekhanabad } \\
\text { district, } 2014 \text { July }\end{array}$ & $\begin{array}{l}2014 \\
\text { Decembe } \\
r\end{array}$ & $\begin{array}{l}\text { Uktam farm of Arnasay } \\
\text { district }\end{array}$ \\
\hline 2 & $\begin{array}{l}\text { Kashkhadary region, } \\
\text { Territory of Dekhanabad } \\
\text { district, } 2014 \text { July }\end{array}$ & $\begin{array}{l}2015 \\
\text { Decembe } \\
r\end{array}$ & $\begin{array}{l}\text { Shifo-kovrak farm } \\
\text { Arnasay district }\end{array}$ \\
\hline 3 & $\begin{array}{l}\text { Surkhandarya } \\
\text { from Bovince, } \\
2015 \text {. }\end{array}$ & $\begin{array}{l}2015 \\
\text { Decembe } \\
r\end{array}$ & $\begin{array}{l}\text { Shifo-kovrak farm } \\
\text { Arnasay district }\end{array}$ \\
\hline
\end{tabular}

Our observations show that germination of plant seeds begins in late February and early March. The bud does not develop until the air temperature does not exceed +5 degrees. Therefore, the formation of the first leaf is associated with an increase in air temperature. The ripe, peeled seeds of the stink buckwheat plant are harvested in the summer, stored in air-permeable bags in the shade, and after biological treatment, they are plowed in autumn and early winter - late November and December, to a depth of $35.0-40.0 \mathrm{~cm}$. planted on arable land. The plowed land is plowed, if uneven it is plowed and leveled. Then the plant seeds are sown by hand and up to $8 \mathrm{~kg}$ per hectare depending on the place of its collection The seeds are buried to a depth of $0.5-1.0 \mathrm{~cm}$, if buried deep, the seeds are difficult to germinate from the soil, if left on the ground it is difficult to take root. When planting plantations from seed, it is important to know how much the seedlings have survived in the period before the resin is extracted from them.

Seed germination of F. tadshikorum was $90-95 \%$ in the laboratory and $65-70 \%$ in the field. Experimental work was carried out in 2014-2019 on the territory of the farm "Shifokovrak" in Arnasay district. The experiment was of two kinds: 1) the land was plowed and then the seeds were sown (A). 2) The land was chiseled and then carried out in areas where seeds were sown (B).

\section{Results and Discussions}

The average retention of sown seed grass per $\mathrm{m} 2$ area over the years is given in the table below (Table 2). 
ISSN (e): 2689-1018

DOI: https://doi.org/10.37547/tajabe/Volume02Issue07-05

Table 2

The preservation of foul-smelling grasses over the years

\begin{tabular}{|c|c|c|c|c|c|}
\hline \multirow[t]{3}{*}{ № } & 1 year, & 2 year, & 3 year, & 4 year, & 5 year, \\
\hline & \multicolumn{5}{|c|}{ The number of lawns } \\
\hline & \begin{tabular}{|l|} 
number \\
\end{tabular} & number & number & number & number \\
\hline 1 & \multicolumn{5}{|c|}{$\begin{array}{l}\text { Kashkhadary region, Territory of Dekhanabad district, Date of } \\
\text { germination, planted in December } 2014 \text { on the territory of the } \\
\text { farm " Uktam " Arnasay district. }\end{array}$} \\
\hline $\mathbf{A}^{x}$ & 98 & 50 & 28 & 18 & 8 \\
\hline$B^{x}$ & 71 & 31 & 22 & 15 & 6 \\
\hline 2 & \multicolumn{5}{|c|}{$\begin{array}{l}\text { From the territory of Dekhanabad, Kashkhadary region, in July } \\
2014 \text {; It was planted in December } 2015 \text { on the territory of } \\
\text { "Shifokovrak" farm in Arnasay district } \\
\text { release date }\end{array}$} \\
\hline A & 100 & 55 & 30 & 20 & 10 \\
\hline $\mathbf{D}$ & 75 & 34 & 25 & 16 & 8 \\
\hline 3 & \multicolumn{5}{|c|}{$\begin{array}{l}\text { Surkhandarya region, from Bobotag, collected in July 2015; Date } \\
\text { of germination, planted in December } 2015 \text { on the territory of the } \\
\text { farm "Shifokovrak" Arnasay district. }\end{array}$} \\
\hline A & 102 & 84 & 34 & 22 & 11 \\
\hline B & 85 & 34 & 24 & 18 & 9 \\
\hline
\end{tabular}

$A^{\times}$- planted as a plow, $B^{\times-}$seeds sown as chisels.

It is known from the table that almost half of the seeds sown in all experimental areas do not germinate, and the number of sprouted grasses is on average $55-70 \%$.

The seeds harvested in July 2014 from Dehkanabad district, Kashkadarya region. When planted in December 2014 in the area of Uktam farm, Arnasay district, 98 grassess per square meter grew in variant $A, 71$ grassess in variant $B$, of which 8 or 6 number of ferulas that survived for 5 years. In the remaining variantss, the number of ferulas has declined sharply over the years. This means that planting resin-bearing ferulas in plowed fields gives better results than in chisel-planted areas.

According to our observations, up to 120 grasses per $1 \mathrm{~m} 2$ area were observed in the spring of the following year (April 10, 2014) around 1 bush fertilized around the village of Ukhum on Mount Nurata. The number of plants that entered the generative period (flowering) in this area was 8-10 per $1 \mathrm{~m} 2$. This means that in nature, even if every fragile plant produces thousands of seeds, only $4-5 \%$ of the grass that grows in nature will survive until it blooms.

Therefore, the number of bushes of resin-bearing husks should be $8 \mathrm{~kg} / \mathrm{ha}$ in the years of resin extraction (5-6 years of vegetation) so that 10 thousand seedlings per hectare would remain. If the seed to be sown is less than this amount, we will not be able to prepare the expected number of seedlings.

\section{Conclusion}

In conclusion, it should be noted that there is an opportunity to sow and multiply the 
seeds of resin-bearing ferulas in the arable lands of Arnasay district, and the ferulas (in 56 years of vegetation) the amount of seeds that can be sown should be up to $8-10 \mathrm{~kg} / \mathrm{per}$ hector. If the seed to be sown is less than this amount, we will not be able to prepare the expected number of seedlings. Plant vegetation continues to grow steadily for 5-6 years.

\section{References}

1. Resolution of the Cabinet of Ministers of the Republic of Uzbekistan dated April 23, 2018 No 299.

2. Korovin E.P. Sem. Zontichnye // Flora Uzbekskoy SSR. - Tashkent. 1959. T. 4. S. 459 .

3. Korotkova E.E. Kraxmalonosnye i saxaronosnye rasteniya // Syrevye resursy Uzbekistana. 1942.

4. Raxmankulov U. Terpenoidosoderjashchie Zapadnogo plantsTyan-Shanya and ix use: avtoref. dis. ... d-ra biol. nauk / U. Raxmankulov. - Tashkent, 1999. - 39 p.

5. Raxmankulov U., Melibaev S. Some biological features of the Mediterranean species Ferula L. // Biological features and distribution of perspective medicinal plants. Tashkent: Fan, 1981a. -S. 31-61.

6. Raxmankulov U., Melibaev S., Saidxodjaev A.I. Sredneaziatskie vidy roda Ferula L. Istochnik seskviterpenovyx proizvodnyx // Biologicheskoe osobennosti i rasprostranenie perspektivnyx lekarstvennyx rasteniy. -Tashkent: Fan, 1981. -S. 138-153.

7. Saidxodjaev A.I. Terpenoid plants of the genus Ferula L. Avtoref. diss. doctor xim. science. 1984. 26 p.

8. Ramenskiy L.G. O printsipialnyx ustanovkax, osnovnyx ponyatiyax i terminax proizvodstvennoy tipologii zemel, geobotaniki i ekologii // Sov. botan. 1935. 4. S.. 25-42.

9. Ramenskiy I.A., Tsatsenkin O.I., Chijikova N.A., Antipin N.A. Ekologicheskaya otsenka kormovyx ugodiy po rastitelnomu pokrovu. M .: Izd-vo s-x. lit. 1956. S. 41-46.

10. Serebryakov I.G. Ecological morphology of plants. M .: Gos. Izdat. Vysshaya school. 1962. 375 p.

11. Serebryakov I.G., Serebryakova T.I. Ecological morphology of plants growing in the USSR // Botan. jurn. 1967. T. 52. 10. S. 1449-1471.

12. Taxtadjyan A.L. Proisxojdenie i rasselenie tsvetkovyx rasteniy. L. Science. 1970. 148 p.

13. Cherepanov S.K. Sosudistye rasteniya SSSR. L. Science. 1981. 509 p.

14. Pimenov M.G. Section Glaucoselinumek (Schischk) M. Pimen. genus Ferula L. (Umbelliferae). Biological sciences. 1983. Botany. 12. S. 74-78.

15. Safina L.K., Pimenov M.G. Feruly to Kazakhstan. Alma-Ata. Science. 1984. 160

p.

16. Rahmonqulov U., Avalboev O.N. Fractions of Uzbekistan (biology, resources and their rational use). -T .: «Science and technology», 2016, page 244.

17.S. Rakhimov, G.R. Denisova "Some features of the underground organs of Ferula tadshikorum M. Pimen." (Ferula L.) Bulletin of Altai State Agrarian University No. 8 (154), 201787.

18. Halkuzieva M.A, Rahmonkulov U. Bulletin of Khorezm Mamun Academy "Ways to get regin from Ferules". Khiva-2020-4 / 1 №.-B 37-41 